[Chem. Pharm. Bull.

35(12)4960-4963(1987) $]$

\title{
One-Step Preparation of 1-Alkenyltriphenylphosphonium Perchlorates by Electrochemical Oxidation of Triphenylphosphine in the Presence of Alkenes
}

\author{
Hidenobu Ohmori, ${ }^{*}$ Toshikatsu Takanami, and Masaichiro Masui \\ Faculty of Pharmaceutical Sciences, Osaka University, \\ 1-6 Yamadaoka, Suita, Osaka 565, Japan
}

(Received April 17, 1987)

\begin{abstract}
Electrochemical oxidation of triphenylphosphine in dichloromethane at a graphite anode in the presence of olefins has been shown to be a convenient method for the preparation of 1alkenyltriphenylphosphonium perchlorates under mild conditions.
\end{abstract}

Keywords_-triphenylphosphine; 1-alkenyltriphenylphosphonium perchlorate; alkene; electrochemical oxidation; constant current electrolysis

Triphenylvinylphosphonium bromide (Schweizer's reagent) ${ }^{1)}$ and related 1-alkenylphosphonium salts are useful building blocks for the synthesis of carbocyclic ${ }^{2)}$ and heterocyclic ${ }^{3)}$ compounds, allylamines, ${ }^{4)}$ and 1,4-dienes. ${ }^{5)}$ Applications of 1-cycloalkenyltriphenylphosphonium salts to the synthesis of carbocyclic and heterocyclcic compounds and optically active organophosphorus compounds have also been reported. ${ }^{6,7)}$ However, the preparation of the phosphonium salts usually involves rather troublesome multistep procedures. ${ }^{1,8,9)} \mathrm{On}$ the other hand, we found recently that electrochemical oxidation of triphenylphosphine (1) in the presence of olefins (2) can be an efficient method to prepare 1-alkenyltriphenylphosphonium salts $(3)^{10)}$ : 1-cycloalkenyl derivatives $\left(\mathrm{C}_{5}-\mathrm{C}_{8}\right)$ were obtained in $50-70 \%$ yields. This paper reports further examples of electrochemical preparation of 3 (Chart 1), including triphenylvinylphosphonium perchlorate (3f).

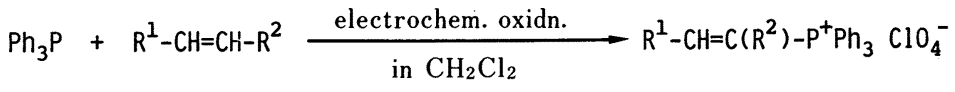

1

2

3

Chart 1

\section{Results and Discussion}

As described previously, $\left.{ }^{10}\right)$ the phosphonium salt 3 was obtained by constant current electrolysis of a mixture of 1 and 2 in dry dichloromethane containing 2,6-lutidinium perchlorate $\left(\mathrm{LutClO}_{4}\right)$ in an undivided electrolysis cell. The results are shown in Table I.

Since the oxidation potentials of the olefins used are higher than that $1,{ }^{11)}$ the process for the formation of 3 can be represented as shown in Chart 2 by analogy with the reactions of triphenylphosphine radical cation (4) with other nucleophiles. ${ }^{12)} \mathrm{LutClO}_{4}$ acts as a proton carrier, that is, it is reduced to the free base at the cathode and the latter accepts the proton liberated at the anode.

In the electrolysis with $\mathbf{2 a}, \mathbf{2 c}$, and $\mathbf{2 d}$, the phosphonium salts listed in Table I were 
TABLE I. Electrochemical Preparation of $3^{a)}$

\begin{tabular}{llc}
\hline \hline Olefin 2 (amount (mmol)) & \multicolumn{1}{c}{ Product $3^{b)}$} & Yield $(\%)^{c)}$ \\
\hline a 1-Methylcyclohexene (15) & $\left(\right.$ 2-Methylcyclohexen-1-yl) $\mathrm{P}^{+} \mathrm{Ph}_{3}$ & 41 \\
b Cyclohexene (15) & $\left(\right.$ Cyclohexen-1-yl) $\mathrm{P}^{+} \mathrm{Ph}_{3}$ & $53^{d)}$ \\
c Styrene (3) & $\mathrm{C}_{6} \mathrm{H}_{5} \mathrm{CH}=\mathrm{CH}-\mathrm{P}^{+} \mathrm{Ph}_{3}$ & 79 \\
d 4-Methylstyrene (3) & $p-\mathrm{Me}-\mathrm{C}_{6} \mathrm{H}_{4} \mathrm{CH}=\mathrm{CH}-\mathrm{P}^{+} \mathrm{Ph}_{3}$ & $c a .100$ \\
e $1,3-$ Cyclohexadiene (5) & $(1,3-\mathrm{Cyclohexadien}-1-\mathrm{yl}) \mathrm{P}^{+} \mathrm{Ph}_{3}$ & $92^{e)}$ \\
f Ethylene (saturated) & $\mathrm{CH}_{2}=\mathrm{CH}-\mathrm{P}^{+} \mathrm{Ph}_{3}$ & $30^{f)}$ \\
\hline
\end{tabular}

a) General procedure, see Experimental (amount of 1, $3 \mathrm{mmol}$ ). b) Counter anion, $\mathrm{ClO}_{4}{ }^{-}$. c) Isolated yield based on 1. d) Quoted from ref. 10. e) Obtained as a crude product, see the text. $f$ ) At $0{ }^{\circ} \mathrm{C}$, see Experimental.

$$
\begin{aligned}
& 1 \stackrel{-e}{\longrightarrow} \mathrm{Ph}_{3} \mathrm{P}^{+\cdot} \stackrel{+2}{\longrightarrow} \mathrm{R}^{1}-\mathrm{CH}^{+}-\mathrm{CH}\left(\mathrm{R}^{2}\right)-\dot{\mathrm{PPh}}_{3} \stackrel{-e,-\mathrm{H}^{+}}{\longrightarrow} 3 \\
& 4
\end{aligned}
$$

Chart 2

isolated, and no other compound derived from 1 and the olefins was obtained. The yield of 3a was lower than that of $\mathbf{3 b}$ under the same electrolysis conditions. In $\mathbf{2 a}$ only one position is available for the attack of the radical cation 4 to give 3a, that is, the 2-position, while $\mathbf{3 b}$ will be formed by the reaction of $\mathbf{4}$ with $\mathbf{2 b}$ at either of the two olefinic carbons. In the case of $\mathbf{2 c}$ and $\mathbf{2 d}$, the radical cation $\mathbf{4}$ seems to attack preferentially at the position in the molecule with highest frontier electron density. ${ }^{13)}$ The proton nuclear magnetic resonance $\left({ }^{1} \mathrm{H}-\mathrm{NMR}\right)$ spectra of 3c and 3d, which exhibit signals due to two vinyl protons with $J_{\mathrm{HH}}=18 \mathrm{~Hz}$, suggest ${ }^{14)}$ that the phosphonium salts are trans isomers. Although the phosphonium salt $3 \mathbf{e}$ was suggested, on the basis of spectroscopic data (see Experimental), to be the major component of the product isolated in the electrolysis with $\mathbf{2 e}$, it could not be separated from small amounts of impurities. When the product was treated with sodium hydroxide according to the known procedure, ${ }^{9)}$ (1,3-cyclohexadien-1-yl)diphenylphosphine oxide (5e) was obtained in $62 \%$ yield. In an attempt to prepare the phosphonium salts of the type, $\mathrm{R}-\mathrm{CH}_{2}-$ $\mathrm{CH}=\mathrm{CH}-\mathrm{P}^{+} \mathrm{Ph}_{3} \mathrm{ClO}_{4}{ }^{-}(3 \mathrm{~g})$, electrolysis of 1 with 1-heptene was examined. An oily product mixture containing some phosphonium salt was obtained, but separation of the mixture into each component has not yet been achieved. In this case, treatment of the mixture with sodium hydroxide did not give the expected alkenyldiphenylphosphine oxide: $\mathrm{Ph}_{3} \mathrm{PO}$ was isolated from the reaction.

The present results together with those reported previously ${ }^{10)}$ may suggest the possibility of preparing various 1-alkenyltriphenylphosphonium salts by electrochemical oxidation. However, further investigation is required to obtain the phosphonium salts $\mathbf{3 g}$ and to improve the yield of the vinylphosphonium salt $\mathbf{3 f}$.

\section{Experimental}

All melting points are uncorrected. Infrared (IR) and ${ }^{1} \mathrm{H}-\mathrm{NMR}$ spectra were measured with Nippon-Bunko A202, and Hitachi R-20 (60 MHz) or JEOL GX-400 (400 MHz) spectrometers, respectively. Constant current electrolysis was carried out using a Hokuto Denko HA-301 and HA-111 potentiostat/galvanostat.

Materials_- $\mathrm{LutClO}_{4}$ was prepared as described previously. ${ }^{15)}$ Dichloromethane was distilled from $\mathrm{P}_{2} \mathrm{O}_{5}$ and stored over molecular sieves. Other organic compounds were obtained from commercial sources and were purified by distillation or recrystallization.

General Procedure for the Preparation of 3-A $50 \mathrm{ml}$ sample tube fitted with a silicon stopper was used as the electrolysis cell. A graphite plate anode $\left(10.5 \times 2 \mathrm{~cm}^{2}\right)$ and a stainless steel plate cathode $\left(2.8 \times 2 \mathrm{~cm}^{2}\right)$ were placed in 
the cell at a distance of $c a .1 \mathrm{~cm}$ through the stopper. A solution of $1(3 \mathrm{mmol})$ and 2 (amount, see Table I) in dry, deoxygenated $\mathrm{CH}_{2} \mathrm{Cl}_{2}(40 \mathrm{ml})$ containing $0.2 \mathrm{M} \mathrm{LutClO}_{4}$, and anhydrous $\mathrm{K}_{2} \mathrm{CO}_{3}(3 \mathrm{~g}$, suspended) were placed in the electrolysis cell. The system was subjected to electrolysis $\left(20 \mathrm{~mA}\right.$; current density, ca. $\left.1 \mathrm{~mA} / \mathrm{cm}^{2}\right)$ at ambient temperature under an $\mathrm{N}_{2}$ atmosphere until $2 \mathrm{~F}$ per mol of $1(579 \mathrm{C}, c a .8 \mathrm{~h})$ had been consumed: the $\mathrm{N}_{2}$ gas was supplied from a balloon connected to the cell by a hypodermic needle. The electrolyzed solution, after the $\mathrm{K}_{2} \mathrm{CO}_{3}$ had been removed by filtration, was evaported to $c a$. $1-2 \mathrm{ml}$ under reduced pressure. Water $(100 \mathrm{ml})$ was added to the residue, and the mixture was extracted with $\mathrm{CHCl}_{3}(50 \mathrm{ml} \times 4)$. The extracts were dried with anhydrous $\mathrm{MgSO}_{4}$ and conçentrated to $c a .5 \mathrm{ml}$ under reduced pressure. The phosphonium salt 3 separated out when the residue was added dropwise to ether $(100 \mathrm{ml})$ with stirring.

(2-Methy-1-cyclohexen-1-yl)triphenylphosphonium Perchlorate (3a): $\mathrm{mp} 178-180^{\circ} \mathrm{C}$ (from $\mathrm{CH}_{2} \mathrm{Cl}_{2}$-ether). IR $v_{\max }^{\mathrm{CHCl}_{3}} \mathrm{~cm}^{-1}: 1590(\mathrm{C}=\mathrm{C}), 1100\left(\mathrm{ClO}_{4}^{-}\right)$. NMR $\left(\mathrm{CDCl}_{3}\right) \delta: 1.2-2.5(11 \mathrm{H}, \mathrm{m}), 7.5-8.2(15 \mathrm{H}, \mathrm{m})$. Anal. Calcd for $\mathrm{C}_{25} \mathrm{H}_{26} \mathrm{ClO}_{4} \mathrm{P}: \mathrm{C}, 65.72 ; \mathrm{H}, 5.74 ; \mathrm{Cl}, 7.76$. Found: $\mathrm{C}, 65.71 ; \mathrm{H}, 5.73 ; \mathrm{Cl}, 7.84$.

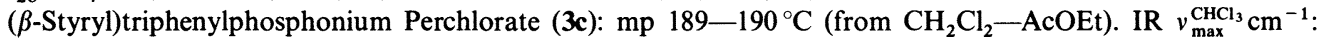
$1600(\mathrm{C}=\mathrm{C}), 1100\left(\mathrm{ClO}_{4}{ }^{-}\right)$. NMR $\left(\mathrm{CDCl}_{3}\right) \delta: 7.17\left(1 \mathrm{H}, \mathrm{dd}, J_{\mathrm{PH}}=23 \mathrm{~Hz}, J_{\mathrm{HH}}=18 \mathrm{~Hz}\right), 7.40-7.45\left(3 \mathrm{H}, \mathrm{m}, \mathrm{H}^{m}\right.$ and $\left.\mathrm{H}^{p}\right), 7.51\left(1 \mathrm{H}, \mathrm{dd}, J_{\mathrm{PH}}=21 \mathrm{~Hz}, J_{\mathrm{HH}}=18 \mathrm{~Hz}\right), 7.65-7.95\left(17 \mathrm{H}, \mathrm{m}, \mathrm{Ph}_{3} \mathrm{P}\right.$ and $\left.\mathrm{H}^{o}\right)$. Anal. Calcd for $\mathrm{C}_{26} \mathrm{H}_{22} \mathrm{ClO}_{4} \mathrm{P}: \mathrm{C}_{\text {, }}$ 67.18; H, 4.77; Cl, 7.63. Found: C, 67.10; H, 4.71; Cl, 7.45.

[ $\beta$-(4-Methyl)styryl]triphenylphosphonium Perchlorate (3d): $\mathrm{mp} 221-223^{\circ} \mathrm{C}$ (from $\mathrm{CH}_{2} \mathrm{Cl}_{2}-\mathrm{AcOEt}$ ). IR $v_{\max }^{\mathrm{CHCl}_{3}} \mathrm{~cm}^{-1}: 1600(\mathrm{C}=\mathrm{C}), 1100\left(\mathrm{ClO}_{4}{ }^{-}\right) . \mathrm{NMR}\left(\mathrm{CDCl}_{3}\right) \delta: 2.46\left(3 \mathrm{H}, \mathrm{s}, \mathrm{CH}_{3}\right), 7.14\left(1 \mathrm{H}, \mathrm{dd}, J_{\mathrm{PH}}=23 \mathrm{~Hz}, J_{\mathrm{HH}}=18 \mathrm{~Hz}\right)$, $7.35\left(2 \mathrm{H}\right.$, br d, $\left.J=9 \mathrm{~Hz}, \mathrm{H}^{m}\right), 7.41\left(1 \mathrm{H}, \mathrm{dd}, J_{\mathrm{PH}}=21 \mathrm{~Hz}, J_{\mathrm{HH}}=18 \mathrm{~Hz}\right), 7.6-8.0\left(17 \mathrm{H}, \mathrm{m}, \mathrm{Ph}_{3} \mathrm{P}\right.$ and $\left.\mathrm{H}^{o}\right)$. Anal. Calcd for $\mathrm{C}_{27} \mathrm{H}_{24} \mathrm{ClO}_{4} \mathrm{P}: \mathrm{C}, 67.72 ; \mathrm{H}, 5.05 ; \mathrm{Cl}, 7.40$. Found: $\mathrm{C}, 67.94 ; \mathrm{H}, 5.11 ; \mathrm{Cl}, 7.17$.

Electrolysis of $1(786 \mathrm{mg})$ in the presence of $2 \mathrm{e}(400 \mathrm{mg})$ followed by work-up as described above gave a crystalline solid as the product $(1210 \mathrm{mg})$. The following spectral data, together with the ${ }^{13} \mathrm{C}-\mathrm{NMR}$ spectra of vinyland allylphosphonium salts, ${ }^{16)}$ suggest that $(1,3$-cyclohexadien-1-yl)triphenylphosphonium perchlorate (3e) is the main component of the product. IR $v_{\max }^{\mathrm{KBr}} \mathrm{cm}^{-1}: 1620$ and 1585 (conjugated diene), $1100\left(\mathrm{ClO}_{4}{ }^{-}\right) .{ }^{1} \mathrm{H}-\mathrm{NMR}\left(\mathrm{CD} \mathrm{CN}_{3} \mathrm{CN}\right.$ $\delta: 2.37-2.45(4 \mathrm{H}, \mathrm{m}), 6.23-6.27(1 \mathrm{H}, \mathrm{m}, \mathrm{H}$ on $\mathrm{C} 3), 6.42-6.48(1 \mathrm{H}, \mathrm{m}, \mathrm{H}$ on $\mathrm{C} 4), 6.71\left(1 \mathrm{H}, \mathrm{dd}, J_{\mathrm{PH}}=20 \mathrm{~Hz}\right.$, $J_{\mathrm{HH}}=5.5 \mathrm{~Hz}, \mathrm{H}$ on C2), $7.68-7.93(15 \mathrm{H}, \mathrm{m}, \mathrm{Ar}) .{ }^{13} \mathrm{C}-\mathrm{NMR}$ (DMSO- $\left.d_{6}\right) \delta\left[J_{\mathrm{PC}}(\mathrm{Hz})\right.$, assignment]: 113.4 [84.7, C1], 146.5 [9.2, C2], 123.8 [16.0, C3], 136.8 [9.2, C4], 21.7 [8.4, C5 or C6], 22.9 [6.9, C6 or C5], 117.0 [89.3, $\mathrm{P}^{+}-\mathrm{C}$ of Ph], $134.1[10.7, o-\mathrm{C}], 130.4[13.0, m-\mathrm{C}], 135.1[3.1, p-\mathrm{C}]$. Treatment of the product $(900 \mathrm{mg}, \mathrm{ca} .2 \mathrm{mmol}$ as $3 \mathbf{e})$ with $\mathrm{NaOH}$ in $\mathrm{H}_{2} \mathrm{O}-\mathrm{EtOH}$ according to the reported procedure ${ }^{9)}$ followed by column chromatography on silica gel [AcOEthexane (5:1)] gave (1,3-cyclohexadien-1-yl)diphenylphosphine oxide (5e) $(351 \mathrm{mg}, 62 \%): \mathrm{mp} 139-140^{\circ} \mathrm{C}$ (from hexane). IR $v_{\max }^{\mathrm{CHCl}_{3}} \mathrm{~cm}^{-1}: 1630$ and 1600 (conjugated diene). NMR( $\left.\mathrm{CDCl}_{3}\right) \delta: 2.2-2.4(4 \mathrm{H}, \mathrm{m}), 6.00-6.12(2 \mathrm{H}, \mathrm{m})$, $6.38\left(1 \mathrm{H}, \mathrm{brdd}, J_{\mathrm{PH}}=11 \mathrm{~Hz}, J_{\mathrm{HH}}=3.5 \mathrm{~Hz}\right), 7.35-7.95(10 \mathrm{H}, \mathrm{m})$. Anal. Calcd for $\mathrm{C}_{18} \mathrm{H}_{17}$ OP: C, 77.13; H, 6.11. Found : C, 76.86, H, 6.02.

Triphenylvinylphosphonium Perchlorate (3f) - Ethylene was bubbled through the solution of 1 (786 mg) in dry $\mathrm{CH}_{2} \mathrm{Cl}_{2}(40 \mathrm{ml})$ containing $0.2 \mathrm{M} \mathrm{LutClO}_{4}$ and suspended $\mathrm{K}_{2} \mathrm{CO}_{3}$ for $30 \mathrm{~min}$. The mixture was electrolyzed at $0{ }^{\circ} \mathrm{C}$ as described above. Work-up of the electrolyzed solution gave $3 \mathrm{f}(350 \mathrm{mg})$ : $\mathrm{mp} 134-136^{\circ} \mathrm{C}$ (from $\mathrm{CH}_{2} \mathrm{Cl}_{2}-\mathrm{ether}$ ). IR

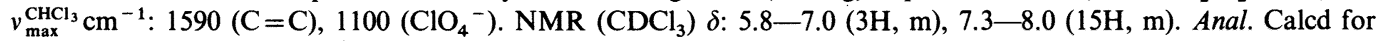
$\mathrm{C}_{20} \mathrm{H}_{18} \mathrm{ClO}_{4} \mathrm{P}: \mathrm{C}, 61.79 ; \mathrm{H}, 4.67 ; \mathrm{Cl}, 9.12$. Found: $\mathrm{C}, 62.11 ; \mathrm{H}, 4.63 ; \mathrm{Cl}, 9.22$.

Acknowledgement This work was supported in part by a Grant-in-Aid for Scientific Research (60570987) from the Ministry of Education, Science and Culture.

\section{References and Notes}

1) E. E. Schweizer and R. D. Bach, J. Org. Chem., 29, 1746 (1964).

2) R. Bonjouklian and R. A. Ruden, J. Org. Chem., 42, 4095 (1977); I. Kawamoto, S. Muramatsu, and Y. Yura, Tetrahedron Lett., 1974, 4223; A. T. Hewson, ibid., 1978, 3267; A. T. Hewson and D. T. MacPherson, ibid., 1983, 5807; A. G. Cameron and A. T. Hewson, J. Chem. Soc., Perkin Trans. 2, 1983, 2979; M. E. Kuehne and R. J. Reider, J. Org. Chem., 50, 1464 (1985); and references cited therein.

3) E. E. Schweizer, J. Am. Chem. Soc., 86, 2744 (1964); E. E. Schweizer, S. D. Goff, and W. P. Murray, J. Org. Chem., 42, 200 (1977); E. Zbiral, Synthesis, 1974, 775; K. B. Becker, Tetrahedron, 36, 1717 (1980); J. V. Cooney, B. D. Beaver, and W. E. McEwen, J. Heterocycl. Chem., 22, 635 (1985); and references cited therein.

4) A. J. Meyers, J. P. Lawson, and D. R. Carver, J. Org. Chem., 46, 3119 (1981).

5) G. Just and B. O'Connor, Tetrahedron Lett., 26, 1799 (1985).

6) T. Minami, H. Sako, T. Ikehira, T. Hanamoto, and I. Hirao, J. Org. Chem., 48, 2569 (1983); T. Minami, Y. Taniguchi, and I. Hirao, J. Chem. Soc., Chem. Commun., 1984, 1046; T. Minami, T. Hanamoto, and I. Hirao, J. Org. Chem., 50, 1278 (1985); T. Minami, T. Chikugo, and T. Hanamoto, ibid., 51, 2210 (1986).

7) T. Minami, Y. Okada, Y. Taniguchi, R. Nomura, and I. Hirao, The 13th Symposium on Organic Sulfur and Phosphorus Chemistry, Hiroshima, 1985, Abstract p. 21; T. Minami, Y. Okada, R. Nomura, S. Hirota, Y. Nagahara, and K. Fukuyama, Chem. Lett., 1986, 613. 
8) E. E. Schweizer and A. T. Wehman, J. Chem. Soc. $(C)$, 1971, 343; E. E. Schweizer, A. T. Wehman, and D. M. Nycz, J. Org. Chem., 38, 1583 (1973).

9) G. Saleh, T. Minami, Y. Ohshiro, and T. Agawa, Chem. Ber., 112, 355 (1979).

10) H. Ohmori, T. Takanami, and M. Masui, Tetrahedron Lett., 26, 2199 (1985).

11) The voltammetric peak potentials of 1 and 2 in acetonitrile $\left(0.1 \mathrm{M} \mathrm{NaClO}_{4}\right)$ were as follows: $1,1.4 ; 2 \mathbf{a}, 2.0 ; 2 \mathbf{b}$, $2.1 ; 2 \mathrm{c}, 1.8 ; 2 \mathrm{~d}, 1.8 ; 2 \mathrm{e}, 1.5 \mathrm{~V} v \mathrm{~s}$. $\mathrm{Ag}$ wire (at a glassy carbon electrode, at $25^{\circ} \mathrm{C}$; voltage sweep rate, $50 \mathrm{mV} \mathrm{s}^{-1}$ ).

12) H. Ohmori, K. Sakai, N. Nagai, Y. Mizuki, and M. Masui, Chem. Pharm. Bull., 33, 373 (1985) and references cited therein.

13) Simple molecular orbital calculation showed that the $\beta$ position of the styrenes meets the requirement.

14) L. M. Jackmann and S. Sternhell, "Application of Nuclear Magnetic Resonance Spectroscopy in Organic Chemistry," 2nd ed., Pergamon Press, Oxford, 1969, pp. 301-304.

15) H. Ohmori, T. Takanami, H. Shimada, and M. Masui, Chem. Pharm. Bull., 35, 2558 (1987).

16) T. A. Albright, W. J. Freeman, and E. E. Schweizer, J. Am. Chem. Soc., 97, 2946 (1975) and references cited therein. 